\title{
Occurrence of ants (Hymenoptera: Formicidae) in Banisteriopsis laevifolia (A.Juss.) B.Gates (Malpighiaceae) in São Paulo State, Brazil
}

\author{
R. Sebastiani ${ }^{a}$, R. T. Fujihara ${ }^{a}$ and M. Garcia ${ }^{b}$ \\ ${ }^{a}$ Departamento de Ciências da Natureza, Matemática e Educação, Centro de Ciências Agrárias, \\ Universidade Federal de São Carlos - UFSCar, Rodovia Anhanguera, Km 174, CP 153 , \\ CEP 13600-970, Araras, SP, Brazil \\ 'Instituto de Ciências da Saúde, Universidade Paulista - UNIP, Rua Apeninos, 127, Campus Vergueiro, \\ CEP 01533-000, São Paulo, SP, Brazil \\ *e-mail: renatasebastiani2014@gmail.com
}

Received: March 23, 2016 - Accepted: May 19, 2016 - Distributed: August 31, 2017

Containing approximately 75 genera and 1.300 species, Malpighiaceae is one of the most diverse families of tropical and subtropical lianas and shrubs worldwide, which is predominantly distributed within the neotropics (Anderson, 2013). In Brazil, Malpighiaceae is represented by 44 genera and approximately 561 species distributed throughout the country; however diversity is highest within the Brazilian Savanna, a hotspot for conservation priorities (Mittermeier et al., 2005; Mamede et al., 2015).

Most species of Malpighiaceae have nectar secreting glands in the leaves and bracts, also called extrafloral nectaries (EFNs) (Anderson, 1990). These glands often mediate the ant-plant interaction, both for the food supply to the ants, as well as for the additional benefit of minimizing the adverse effect of herbivores, pathogens and weeds (Fernandes et al., 2005; Trager et al., 2010).

In January 2013, many species of ants were observed on the leaves and bracts of inflorescences of Banisteriopsis laevifolia (A.Juss.) B.Gates (Malpighiaceae) in the Biological Reserve of Mogi Guaçu, municipality of Mogi Guaçu, São Paulo State ( $\left.22^{\circ} 18^{\prime} \mathrm{S} ; 47^{\circ} 11^{\prime} \mathrm{W}\right)$. The ants collected were preserved in $70 \%$ alcohol, identified and compared with the Museu de Zoologia da Universidade de São Paulo (MZUSP) collection, municipality of São Paulo, in São Paulo State. Vouchers were collected from B. laevifolia specimens, using the standardized protocols for the collectition and herborization of botanical material; speciments were deposited in the herbarium of Centro de Ciências Agrárias (CCA) at Universidade Federal de São Carlos (UFSCar, HARA herbarium), municipality of Araras, São Paulo State. The species of ants have been filed in the reference collection at the CCA / UFSCar. After reviewing the samples, it has been found that there are three species of ants in two specimens of B. laevifolia (Table 1).

Morais (1980) identified 42 species of ants in the Biological Reserve of Mogi Guaçu, including Camponotus crassus (Mayr, 1862) and Pseudomyrmex gracilis (Fabricius, 1804), but there are no records for Cephalotes minutus (Fabricius, 1804). Alves-Silva et al. (2013) reported that $C$. crassus are generally observed in EFNs and are
Table 1. Ant species present in Banisteriopsis laevifolia (A.Juss.) B.Gates (Malpighiaceae) in Mogi Guaçu Biological Reserve, São Paulo State, Brazil.

\begin{tabular}{ccc}
\hline Ant species & Ant subfamily & Plant voucher \\
\hline Camponotus & Formicinae & Sebastiani et al. \\
crassus & & 414 (HARA) \\
(Mayr, 1862) & & \\
Pseudomyrmex & Pseudomyrmecinae & Sebastiani et al. \\
gracilis & & 414 (HARA) \\
(Fabricius, 1804) & & \\
Cephalotes & Myrmicinae & Sebastiani et al. \\
minutus & & 433 (HARA) \\
(Fabricius, 1804) & & \\
\hline
\end{tabular}

extremely aggressive against herbivorous insects as well as other predators. According to Dansa (1989), P. gracilis preferably uses insects (dead or alive) and nectar as a food source, especially EFNs. C. minutus is considered a "generalist Myrmicinae" in relation to resource and habitat use (Andersen, 1995), being less dependent than nectar subdominant ants (Davidson et al., 2003).

In $B$. laevifolia, the occurrence of C. crassus is previously known (Torezan-Silingardi, 2007). However, this is the first record of $P$. gracilis and C. minutus for this botanical species.

\section{Acknowledgements}

We would to thank the administration of Mogi-Guaçu Biological Reserve for the assistance in field sampling.

\section{References}

ALVES-SILVA, E., BARÔNIO, G.J., TOREZAN-SILINGARDI, H.M. and DEL-CLARO, K., 2013. Foraging behavior of Brachygastra lecheguana (Hymenoptera: Vespidae) on Banisteriopsis malifolia (Malpighiaceae): extrafloral nectar consumption and herbivore predation in a tending ant system. Entomological Science, vol. 16, no. 2, pp. 162-169. http://dx.doi.org/10.1111/ens.12004. 
ANDERSEN, A.N., 1995. A classification of Australian ant communities, based on functional groups which parallel plant lifeforms in relation to stress and disturbance. Journal of Biogeography, vol. 22, no. 1, pp. 15-29. http://dx.doi.org/10.2307/2846070.

ANDERSON, W.R., 1990. The origin of the Malpighiaceae: the evidence from morphology. Memoirs of the New York Botanical Garden, vol. 64, pp. 210-224.

ANDERSON, W.R., 2013. Origins of Mexican Malpighiaceae. Acta Botánica Mexicana, vol. 104, pp. 107-156.

DANSA, C.V.A., 1989. Estratégia de forrageamento de Pseudomyrmex gracilis (Fabr.) (Hymenoptera: Formicidae). Campinas: Universidade Estadual de Campinas, 131 p. Masters Dissertation.

DAVIDSON, D.W., COOK, S.C., SNELLING, R.R. and CHUA, T.H., 2003. Explaining the abundance of ants in lowland tropical rainforest canopies. Science, vol. 300, no. 5621, pp. 969-972. PMid:12738862. http://dx.doi.org/10.1126/science.1082074.

FERNANDES, G.W., FAGUNDES, M., GRECO, M.K.B., BARBEITOS, M.S. and SANTOS, J.C., 2005. Ants and their effects on an insect herbivore community associated with the inflorescences of Byrsonima crassifolia (Linnaeus) H.B.K. (Malpighiaceae). Revista Brasileira de Entomologia, vol. 49, no. 2, pp. 264-269. http://dx.doi.org/10.1590/S0085-56262005000200011.
MAMEDE, M.C.H., SEBASTIANI, R., ALMEIDA, R.F., FRANCENER, A. and AMORIM, A.M.A., 2015 [viewed 22 Jan 2016]. Malpighiaceae: lista de Espécies da Flora do Brasil [online]. Rio de Janeiro: Jardim Botânico do Rio de Janeiro. Available from: http://www.floradobrasil.jbrj.gov.br/jabot/ floradobrasil/FB155

MITTERMEIER, R.A., GIL, P.R., HOFFMAN, M., PILGRIM, J., BROOKS, T., MITTERMEIER, C.G., LAMOUREUX, J. and FONSECA, G.A.B., 2005. Hotspots revisited: earth's biologically richest and most endangered terrestrial ecoregions. Washington: Conservation International. $392 \mathrm{p}$.

MORAIS, H.C., 1980. Estrutura de uma comunidade de formigas arborícolas em vegetação de campo cerrado. Campinas: Universidade Estadual de Campinas, 123 p. Masters Dissertation.

TOREZAN-SILINGARDI, H.M., 2007. A influência dos herbivoros florais, dos polinizadores e das características fenológicas sobre a frutificação de espécies da família Malpighiaceae em um cerrado de Minas Gerais. Ribeirão Preto: Universidade de São Paulo, 182 p. PhD Thesis.

TRAGER, M.D., BHOTIKA, S., HOSTETLER, J.A., ANDRADE, G.V., RODRIGUEZ-CABAL, M.A., MCKEON, C.S., OSENBERG, C.W. and BOLKER, B.M., 2010. Benefits for plants in ant-plant protective mutualisms: a meta-analysis. PLoS One, vol. 5, no. 12, pp. e14308. PMid:21203550. http://dx.doi.org/10.1371/journal. pone. 0014308 . 